\title{
Congenital abnormalities reported in Pelger-Huët homozygosity as compared to Greenberg/HEM dysplasia: highly variable expression of allelic phenotypes
}

\author{
J C Oosterwijk, S Mansour, G van Noort, H R Waterham, C M Hall, R C M Hennekam
}

J Med Genet 2003;40:937-941

l: 1928 the Dutch physician Pelger described two patients with a morphological abnormality of leukocytes that consisted of hypolobulation of the nuclei: there were two lobes instead of the usual five or more and the chromatin structure was coarse and denser. ${ }^{1}$ This was subsequently shown to be a genetic trait by paediatrician Huët. ${ }^{2}$ In the following years many families with Pelger-Huët anomaly (PHA) from different countries were reported and autosomal dominant inheritance was firmly established. ${ }^{3}$ Bilobulated PHA nuclei ("spectacle" or "pince-nez" cells) can also be a transient symptom in the presence of underlying disease (for example, infection, myeloid leukaemia or medication) as part of a "shift to the left" (pseudo PHA), but constitutional PHA is a constant, genetic, and harmless nucleomorphic variant. ${ }^{3}$ The frequency of PHA ranges from $0.01-0.1 \%$, with documented clustering in the region of Gelenau, Germany, where $1 \%$ of the population has PHA. ${ }^{4}$

Homozygosity for PHA was first detected in rabbits, ${ }^{5-7}$ before it was described in man. ${ }^{8-14}$ Ever since, PHA homozygosity has been associated with (skeletal) abnormalities and early lethality, though mainly based on animal data. In 2002, through positional cloning, mutations in the lamin B receptor gene $(L B R)$ on $1 \mathrm{q} 42$ were found to cause $\mathrm{PHA}^{4}$ One single founder mutation was detected in 10 Gelenau families, as well as seven other mutations in 10 families from elsewhere. Homozygosity for the founder mutation was detected in one patient that was previously reported with mild congenital abnormalities and homozygous PHA on haematological investigations. ${ }^{14}$

At about the same time, investigations in autosomal recessive Greenberg/HEM (hydrops, ectopic calcifications, moth-eaten) dysplasia had led to the same gene from quite a different angle. ${ }^{15}$ Greenberg/HEM dysplasia is a rare, early (in utero) lethal skeletal dysplasia, characterised by severe hydrops, short limbed dwarfism and marked disorganisation of chondro-osseous calcification (with a moth-eaten aspect). ${ }^{16}$ Polydactyly and other malformations may be present. ${ }^{15} 1718$ An accumulation of cholesta-8,14-dien-3 $\beta$-ol was detected in fibroblasts of an affected fetus, due to deficiency of $3 \beta$-hydroxysterol $\Delta 14$-reductase. This was caused by a homozygous 7-base pair substitution in exon 13 of $L B R$, leading to a stop codon. ${ }^{15}$ In the patient's mother, more than $60 \%$ of granulocytes appeared to have PHA (the father could not be tested). Since this finding, mutations have been detected in both alleles of $L B R$ in three additional HEM cases (H Waterham, personal communication). Moreover, the relation between PHA and Greenberg/HEM was recently confirmed in a patient of Offiah et $\mathrm{al}^{19}$ where PHA was demonstrated in $>95 \%$ of maternal granulocytes, but not in those of the father ( $S$ Mansour, personal communication).

The finding that PHA (homozygosity) and Greenberg/HEM skeletal dysplasia are allelic disorders sheds new light on the

\section{Key points}

- Pelger-Huët anomaly (PHA) is a benign, autosomal dominant haematological trait characterised by hypolobulation of granulocyte nuclei. PHA homozygosity, however, is associated with skeletal abnormalities and early lethality on the basis of animal studies and case reports. In 2002 PHA was found to be due to heterozygous mutations in the lamin $B$ receptor gene $(L B R)$, and a homozygous $L B R$ mutation was detected in a boy with mild congenital abnormalities. Homozygous mutations in $\mathrm{Lbr}$ cause the ic/ic phenotype in mice.

- Recently it was shown that Greenberg/HEM skeletal dysplasia, an in utero lethal disorder, is caused by a $3 \beta$-hydroxysterol $\Delta^{14}$-reductase deficiency, also due to homozygosity for mutations in the LBR. Moreover, in two Greenberg/HEM cases, PHA was detected in relatives, indicating that PHA and Greenberg/HEM dysplasia are indeed related disorders. To assess the phenotypes and possible clinical overlap, all published cases of PHA homozygosity and of Greenberg/HEM were reviewed.

- In 11 people reported as PHA homozygotes, congenital abnormalities were rarely seen, there was no obvious skeletal dysplasia, nor were there indications for skin abnormalities or early lethality. PHA homozygosity causes increased intrauterine lethality, perinatal death and severe chondrodystrophy with limb defects in rabbits. In $\mathrm{Lbr}$-/- mice there is increased intrauterine lethality, severe ichthyosis and sometimes congenital hydrocephaly and mild syndactyly. Phenotypic similarities to Greenberg/HEM dysplasia are mainly present in homozygous PHA rabbits.

- The results suggest that in human beings, PHA homozygosity is phenotypically distinct from Greenberg/HEM dysplasia. This might be due to allelic heterogeneity, on the basis of the nature and localisation of the LBR mutations involved. However, since the phenotypes may be the extremes of one clinical spectrum, which is also suggested on the basis of animal data, the existence of intermediate phenotypes cannot be ruled out yet.

presumed congenital skeletal abnormalities in PHA homozygosity reported in the literature. We therefore critically

Abbreviations: HEM, hydrops, ectopic calcifications, moth-eaten; LBR, lamin B receptor gene; PHA, Pelger-Huët anomaly 
reviewed all published cases of PHA homozygosity, to assess a possible clinical overlap which might be relevant for genetic counselling and that could help understand the phenotypic variability of homozygous $L B R$ defects.

\section{REVIEW OF REPORTED CASES}

A Medline literature search was used to collect all articles on PHA homozygosity. Of these, all references were checked for additional reports. A total of 11 patients were found with the diagnosis PHA homozygosity..$^{8-14} 2021$

\section{Pelger-Huët homozygosity in human beings}

In 1952 Haverkamp Begeman et al were the first to describe PHA homozygosity in a Dutch girl. ${ }^{8}$ She had convulsions (which ran in the family) and mild psychomotor delay. Apart from mild short stature there were no abnormalities and the skeletal survey was normal. Haematological examination showed round, coarse nuclei in $94 \%$ of the neutrophil granulocytes with clumped chromatin structure, strikingly similar to that in the homozygous PHA rabbit. ${ }^{5}$ Both parents (who were first cousins) had PHA, but the girl's two siblings had normal cellular morphology. Three other siblings had died in the first years of life due to diphtheria, diarrhoea, and convulsions respectively, and the mother had had two miscarriages. It was concluded that, although the haematological picture in humans and rabbits is the same, the disorder is not necessarily lethal in humans and does not always lead to skeletal anomalies. ${ }^{8}$

Ten other patients have subsequently been described: one each from Morocco, ${ }^{9}$ and Romania, ${ }^{10}$ three each from Gelenau, Germany,, 1114 and Italy, ${ }^{20}$ and two from Spain. ${ }^{12} 1322$ The clinical data of all patients are summarised in table 1. Two patients had congenital skeletal abnormalities. Aznar and Vaya $^{12}$ described a girl with postaxial polydactyly of one hand and of both feet, but no other abnormalities on X-ray. Otherwise she was healthy. As 30\% of neutrophil granulocytes had a round nucleus and $66 \%$ an indented nucleus, homozygous PHA was diagnosed and both parents appeared to be PHA heterozygous. However, hexadactyly of all limbs was also observed in the proband's sister (without PHA) and in a cousin of the maternal grandmother (PHA status unknown). Considering the skeletal abnormalities in homozygous PHA rabbits, the authors speculate on a relation between polydactyly and PHA homozygosity in human beings. However, the absence of cosegregation in this family makes a correlation unlikely. Von Siegert et $\mathrm{al}^{14}$ describe a 20 month old boy, with a systolic heart murmur and psychomotor retardation. He also had macrocephaly, a bell shaped thorax, hepatomegaly and muscular hypotonia. Typical PHA homozygous nuclei were found in $96 \%$ of neutrophils and both parents had heterozygous PHA. When he was 16 years old there was a ventricular septum defect (VSD), normal muscle tone, mildly disturbed motor coordination and debilitas. An aetiologic relation with PHA homozygosity was considered unlikely. This patient appeared to have the homozygous founder mutation in $L B R$ affecting mRNA splicing. ${ }^{4}$ A photograph of the boy's hands shows shortened 3rd and 5th metacarpals on the left hand and shortened 3rd to 5th metacarpals of the right hand. This case still had some expression of wild type protein, probably from a trace amount of normally spliced mRNA. No steroid data are available on this case to date.

\section{Pelger-Huët homozygosity in animals}

Undritz was the first to describe Pelger-Huët anomaly in rabbits, both in the heterozygous and in the homozygous state. ${ }^{5}$ Later Klein ${ }^{6}$ and Nachtsheim ${ }^{7}$ extensively reported on the phenotypic effects of PHA homozygosity in these rabbits. In the heterozygous state, the haematological phenotype is almost identical to that in human beings, the disorder is benign and the mode of transmission is autosomal dominant. However, when PHA rabbits were mated, not the expected 223 but only 39 homozygous rabbits were counted of which 27 died perinatally and 10 died within the first months of life. Prenatal lethality occurred in more than $80 \%$ in homozygous PHA rabbits, and only 1 homozygous PHA rabbit survived to adulthood and fathered heterozygous offspring. ${ }^{67}$ Homozygous PHA rabbits showed granulocytes with round or oval nuclei and clumped chromatin. Moreover, they had phocomelia with extremely shortened, curved tubular bones and reduction defects, shortened ribs, and a fixation of the thorax leading to respiratory failure. Hydrops is not mentioned. Histology revealed chondrodystrophy with widened epiphyses and reduced and arrested enchondral ossification, ${ }^{67}$ comparable to that seen in Greenberg/HEM dysplasia. No metabolic or molecular investigations in these rabbits are available to confirm the clinical data.

Latimer et al described the occurrence of PHA in cats, ${ }^{23}$ and subsequently the phenotype of PHA homozygosity in cats. ${ }^{24}$ The latter was the result of a brother-sister mating of two PHA cats. A litter of five kittens was produced of which three were stillborn. One of the stillborn kittens was assumed homozygous for PHA on haematological investigation and also had severe chondrodystrophy-that is, short devi-

Table 1 Summary of clinical findings in 11 reported PHA homozygotes from the literature

\begin{tabular}{|c|c|c|c|c|c|c|c|c|c|}
\hline Patient & Sex & $\begin{array}{l}\text { Age } \\
\text { (years) }\end{array}$ & $\begin{array}{l}\text { Mental } \\
\text { retardation }\end{array}$ & Macrocephaly & Seizures & $\begin{array}{l}\text { Congenital skeletal } \\
\text { defects }\end{array}$ & Additional findings & Reason for investigation & Reference \\
\hline 1 & $f$ & 2.5 & + (mild) & - & + (familial) & $1-$ & mild short stature & retardation & 8 \\
\hline 2 & $\mathrm{~m}$ & 30 & - & - & - & - & - & fever and flu & 9 \\
\hline 3 & $f$ & 46 & - & - & - & - & - & climacteric complaints & 10 \\
\hline 4 & $\mathrm{~m}$ & 56 & - & - & - & - & - & bronchitis & 11 \\
\hline 5 & $\mathrm{~m}$ & 56 & - & - & - & - & arthrosis & pneumonia & 11 \\
\hline 6 & $f$ & 10 & $+($ mild $)$ & + & - & - & - & acute meningitis & 20 \\
\hline 7 & f & 1.5 & - & - & + & $\begin{array}{l}\text { + (familial) post-axial } \\
\text { polydactyly of one } \\
\text { hand and both feet }\end{array}$ & - & Seizures & 12 \\
\hline 8 & f & 82 & - & - & - & - & - & cardiac complaints & 21 \\
\hline 9 & $\mathrm{~m}$ & $?$ & - & - & - & - & - & brother of patient no 8 & 21 \\
\hline 10 & $\mathrm{~m}$ & 30 & - & - & - & - & $\begin{array}{l}\text { mild short stature, } \\
\text { slightly short arms, } \\
\text { dyshidrosis } \\
\text { hyperkyphosis }\end{array}$ & Fuvii-Oever & 1322 \\
\hline 11 & $\mathrm{~m}$ & 16 & + & + & - & $\begin{array}{l}\text { +short metacarpal } \\
3-5 \text { of both hands }\end{array}$ & $\begin{array}{l}\text { hypotonia, VSD, poor } \\
\text { co-ordination }\end{array}$ & Retardation & 414 \\
\hline total & $5 f / 6 m$ & $1.5-82$ & $3 / 11$ & $2 / 11$ & $2 / 11$ & 2/11:variable & $2 / 11$ :short stature & 4/11: infection & \\
\hline
\end{tabular}

$\mathrm{f}$, female; $\mathrm{m}$, male; +, reported to be present; -, not reported to be present, absent. 
ated limbs, twisted tubular bones, vertebral abnormalities, shortened and flaring ribs, widened epiphyses, and abnormal enchondral ossification. The two other stillborns were PHA heterozygous and had no skeletal abnormalities. Of the two live born kittens, one was heterozygous for PHA and healthy; the other had no PHA but did have chondrodystrophy, though less severe. The authors conclude that the chondrodystrophy may well have been unrelated to PHA homozygosity and due to inbreeding of laboratory animals. ${ }^{24}$ No metabolic or molecular data on these cats have been published so far.

Recently, Shultz et $\mathrm{al}^{25}$ demonstrated that mutations in both alleles of the mouse homologue $\mathrm{Lbr}$ cause autosomal recessive ichthyosis in mice, a disorder in which nuclear morphology is very similar to that in PHA homozygosity. Twenty one $i c / i c$ mice were bred and all displayed a thick scaly skin. Moreover, three had soft tissue syndactyly or proximal symphalangism of one or more limbs and three had gross hydrocephaly. Segregation analysis showed that approximately half the homozygous mice died in utero. Three independent deleterious mutations were detected and for one of these, immunohistochemistry revealed complete loss of $L B R$ protein. ${ }^{25}$ The authors hypothesise that the effect on sterol metabolism may cause the ichthyosis. This study demonstrates a relation between abnormal nuclear morphology (-that is, PHA homozygosity), increased in utero lethality, ichthyosis and homozygous mutations in $\mathrm{Lbr}$. It also underscores the highly variable phenotypic expression in mice with respect to limb and brain abnormalities.

\section{Greenberg/HEM skeletal dysplasia in humans}

To date eight cases of Greenberg/HEM dysplasia have been described, all diagnosed prenatally by ultrasound. The characteristics are summarised in table 2. Gross hydrops, extreme micromelia and short ribs dominate the clinical picture, and disturbed ossification ('moth eaten') and sometimes fractures of the long bones are seen on X-rays, together with severe platyspondyly and skull hypomineralisation. ${ }^{45-}$ 192627 Three cases were reported to have post-axial polydactyly of both hands ${ }^{15} 17$ and one case was described with additional abnormalities - that is, omphalocele, intestinal malrotation and lung hypolobulation. ${ }^{18}$ Hydrocephaly or ichthyosis are not reported. The histological picture is dominated by severe disorganisation of cartilage - that is, absence of column formation, defective enchondral ossification and ectopic calcification of cartilage. Although there is some phenotypic variability among the reported cases, all have severe hydrops and show an early (in utero) lethal skeletal dysplasia.
Unfortunately, no data are available on neutrophil granulocytes in Greenberg/HEM cases, to confirm that nuclear morphology is similar to that in PHA homozygosity. We are not aware of possible Greenberg/HEM cases with milder (that is, non-lethal) skeletal dysplasia, but this may be due to ascertainment bias. Unless defects in cholesterol biosynthesis are detected in milder cases of skeletal dysplasia, it remains unlikely that the spectrum of homozygous $3 \beta$-hydroxysterol $\Delta$ 14-reductase deficiency can also include only polydactyly or only shortened metacarpals.

\section{DISCUSSION}

\section{The phenotypic spectrum of PHA homozygosity in human beings, as compared to Greenberg/HEM dysplasia}

Among the 11 published descriptions of patients diagnosed with PHA homozygosity (table 1), we found no convincing case of skeletal dysplasia or other congenital malformations comparable to that described in cases with Greenberg/HEM dysplasia. The fact that three patients were mildly mentally retarded, two patients had convulsions, two patients had macrocephaly and two patients had-dissimilar-hand abnormalities does not permit the delineation of a clear PHA homozygosity "syndrome".

There can be several reasons for the lack of congenital defects in reported cases. First, a mistaken diagnosis can be made. Vaya et $\mathrm{al}^{28}$ reported that in cases of familial PHA, infectious disease can induce nuclear morphology identical to that found in homozygous PHA, - that is "pseudo homozygous PHA". With the exception of von Siegert's patient, which was confirmed molecularly, all patients were diagnosed only haematologically, - that is, on blood smears-and proof of PHA in both parents was only available in five patients. ${ }^{8}{ }^{11-13}$ Without thorough family study or molecular confirmation, this phenocopy of PHA homozygosity is possible in at least half of the cases. Molecular analysis of newly diagnosed homozygous PHA cases will help elucidate this issue. Secondly, ascertainment bias is likely: the reasons for investigating the published cases were varied, and PHA detection was usually a chance occurrence. Moreover, although PHA is a diagnosis that is not easily overlooked, we are not aware of a systemic haematological analysis in (parents of) patients with skeletal dysplasia, and especially not in (very) early lethal cases, such as Greenberg/HEM dysplasia. Thirdly, most cases were described in haematological literature, which may have led to an underreporting of non-haematological findings, such as skeletal defects. Fourthly, there is confusion in the literature on the relation between skeletal defects and PHA: even PHA heterozygosity

Table 2 Summary of findings in eight reported cases of Greenberg /HEM skeletal dysplasia

\begin{tabular}{|c|c|c|c|c|c|c|}
\hline Patient & $\begin{array}{l}\text { Age at diagnosis (weeks } \\
\text { gestation) }\end{array}$ & $\begin{array}{l}\text { Hydrops } \\
\text { calcifications }\end{array}$ & Ectopic platyspondyly & $\begin{array}{l}\text { Micromelia } \\
\text { malformations }\end{array}$ & Other congenital short ribs & Reference \\
\hline 1 & 30 & + & + & + & - & 16 \\
\hline 2 & 20 & + & + & + & - & 16 \\
\hline 3 & 17 & + & + & + & $\begin{array}{l}\text { post-axial polydactyly in } \\
\text { both hands }\end{array}$ & 17 \\
\hline 4 & 28 & + & + & + & $\begin{array}{l}\text { omphalocele, intestinal } \\
\text { prolapse and malrotation, } \\
\text { hypolobulation in right lung }\end{array}$ & 18 \\
\hline 5 & 20 & + & + & + & - & 26 \\
\hline 6 & 23 & + & + & + & - & 27 \\
\hline 7 & 17 & + & + & + & $\begin{array}{l}\text { post-axial polydactyly in } \\
\text { both hands }\end{array}$ & 15 \\
\hline 8 & 14 & + & + & + & post-axial polydactyly in & 19 \\
\hline Total & $(14-30)$ & $8 / 8$ & $8 / 8$ & $8 / 8$ & $3 / 8$ post-axial polydactyly & \\
\hline
\end{tabular}

+ , reported to be present; -, not reported to be present, absent. 
has erroneously been associated with congenital skeletal anomalies in the context of trisomy $13,{ }^{29}$ or Frijns syndrome. ${ }^{30}$

\section{The phenotypic spectrum PHA homozygosity in animals as compared to Greenberg/HEM dysplasia} The skeletal defects in PHA homozygous rabbits are very similar to those described in Greenberg/HEM dysplasia, both clinically and histologically, although hydrops (obligate in Greenberg/HEM) is lacking in animals. The case of chondrodystrophy in cats shows similarities as well, as does the histology. However, the chondrodystrophy and PHA homozygosity does not cosegregate in a littermate, making a syndromal entity less likely. Only a small fraction of affected ic/ic mice have discrete limb abnormalities (syndactyly), whereas X-rays do not show signs of chondrodystrophy. ${ }^{25}$ Thus, skeletal findings in human beings are most similar to those in rabbits homozygous for PHA.

In mice the clinical picture is dominated by ichthyosis, which is not reported in cats, ${ }^{24}$ or in rabbits. ${ }^{67}$ Although ichthyosiform skin lesions are not uncommon in cholesterolopathies, this is not reported in Greenberg/HEM dysplasia or in any of the human PHA homozygotes. Schultz et $\mathrm{al}^{25}$ explained this discrepancy by the fact that ic/ic mice show complete loss of Lbr, whereas the reported human PHA homozygote still expressed some detectable $L B R$ protein. Alternatively, the ichthyosis in Greenberg/HEM dysplasia may not yet have developed at the age of diagnosis (1430 wks gestational age), or could be concealed by maceration.

\section{Survival in PHA homozygosity in animals and in human beings}

In rabbits and mice, there is a striking increase of prenatal and perinatal death in PHA homozygosity, with survival rates of $<20 \%$ and $<50 \%$ respectively. ${ }^{6}{ }^{725}$ In human beings such data are lacking. The mothers of patients 1 and 10 had both had two unexplained abortions. ${ }^{8}{ }^{13}$ In the first family, death in the first years of life of three other children was ascribed to specific diagnoses, and no congenital malformations are reported. ${ }^{8}$ We assume that these findings are a chance occurrence and a link with early lethality seems premature. Detection of a distorted segregation in human beings, however, will be very difficult. In the village of Gelenau, with a carrier frequency of 1 in 100, the chance of homozygosity would be 1 in 40,000 births. Given the fact that homozygosity of the Gelenau founder mutation is clearly non-lethal in at least one case,${ }^{414}$ it would take a lot of carrier couples to approach the problem of possible increased (in utero) lethality in humans.

\section{Related phenotypes, extremes of one spectrum}

On the basis of 11 reported cases so far, we conclude that, although suggested otherwise, PHA homozygosity in man is not associated with a well-defined syndrome of skeletal dysplasia, ichthyosis or congenital abnormalities, or with early lethality. Greenberg/HEM skeletal dysplasia at the same time, was invariably lethal in all eight reported cases. The phenotypes do not show overlap and are therefore distinct. There is however considerable overlap between Greenberg/ HEM dysplasia and PHA homozygosity in rabbits, and to a lesser extend in mice and cats, with respect to radiology, histology and early lethality. This might imply that PHA homozygosity and Greenberg/HEM dysplasia are the extremes of one clinical spectrum, and that intermediate phenotypes may be discovered in the future - for example in cases of unexplained non-lethal skeletal dysplasia.

The LBR gene has two domains: a basic amino-terminal domain of approximately 200 amino acids, which binds to Btype lamins and is involved in retention of the inner nuclear membrane, and an approximately 400 amino acid carboxyl- terminal domain, which shows strong sequence similarity to sterol reductases in several species. ${ }^{31}$ This may (partly) explain the pleiotropic phenomenon that both a "nuclear membrane" phenotype (abnormal nuclear morphology in both the PHA heterozygote and in PHA homozygosity) and a "cholesterolopathy" phenotype (Greenberg/HEM dysplasia in the homozygote) can be due to mutations in the same gene. Indeed in the Greenberg/HEM case, the mutation is in the C-terminal part of $L B R$. However, the eight different mutations (four splice site mutations, two nonsense mutations and two frame shift mutations) detected by Hoffmann et al are dispersed throughout LBR: six out of eight are located in the domain homologous to sterol reductases. This was also the case in the proven PHA homozygote. ${ }^{4}$ The fact that the ic/ic mouse has homozygous $\mathrm{Lbr}$ mutations that predominantly lead to disruption of the sterol reductase homologous domain and cause total absence of gene product, may explain the cutaneous phenotype. ${ }^{25}$ It does not, however, clarify the total lack of skin symptoms in the humans with either PHA homozygosity (one of whom still had some detectable protein) or Greenberg/HEM dysplasia. One could conclude that Greenberg/HEM dysplasia most probably represents the null phenotype of $L b r$-related conditions in humans, whereas hypomorphic or neomorphic mutations in $L B R$ in the homozygous state result in a milder PHA homozygosity phenotype without skeletal manifestations. In this respect the nature of the mutation seems to be more important than the localisation of the mutation within the gene, for determination of the ultimate phenotype.

Greenberg/HEM skeletal dysplasia has been added to the list of MCA syndromes that are caused by defects in sterol metabolism, including Smith-Lemli-Opitz syndrome, Conradi-Hünermann syndrome, CHILD syndrome, and desmosterolosis. ${ }^{32}$ Pelger-Huët anomaly has recently been added to the list of laminopathies, such as Emery-Dreifuss muscular dystrophy, partial lipodystrophy, and mandibuloacral dysplasia. ${ }^{33}$ With Greenberg/HEM skeletal dysplasia and PelgerHuët anomaly respectively, these groups of disorders are now related through $L B R$. Further metabolic and molecular studies in both human beings and animals should help to elucidate the relationship between these phenotypes and so answer the question whether PHA may eventually be a marker of heterozygosity for a severe skeletal dysplasia.

\section{ACKNOWLEDGEMENTS}

Dr. A. Wischmeijer (Ravenna, Italy) for translating the Italian case reports and Dr. R. Pelger (Leiden, the Netherlands) for investigating historical sources.

\section{Authors' affiliations}

J C Oosterwijk, Department of Clinical Genetics, Groningen University Hospital, Groningen, Netherlands

S Mansour, Department of Medical Genetics, St George's Hospital Medical School, London, United Kingdom

G van Noort, Regional Pathology Laboratory, Enschede, Netherlands H R Waterham, R C M Hennekam, Department of Paediatrics, Emma Children's Hospital, Academic Medical Centre, Amsterdam, Netherlands

C M Hall, Department of Radiology, Great Ormond Street Hospital for Children, London, United Kingdom

Correspondence to: Dr J C Oosterwijk, Department of Clinical Genetics, University Hospital Groningen, P.O. Box 30.001, NL-9700RB,

Groningen, Netherlands; i.c.oosterwijk@medgen.azg.nl

\section{REFERENCES}

1 Pelger K. Demonstratie van een paar zeldzaam voorkomende typen van bloedlichaampjes en bespreking der patienten. Ned Tijdschr Geneeskd 1928:72:1178. 
2 Huët GJ. Ueber eine bisher unbekannte familiaere Anomalie der Leukocyten. Klin Wochenschr 1932;11:1264-6.

3 Klein A, Hussar AE, Bornstein S. Pelger-Huët anomaly of the leukocytes. N Engl J Med 1955;253:1057-62.

4 Hoffmann K, Dreger CK, Olins AL, et al. Mutations in the gene encoding the lamin $B$ receptor produce an altered nuclear morphology in granulocytes (Pelger-Huet anomaly). Nat Genet 2002;31:410-4.

5 Undritz E. Das ausschliessliche Vorkommen reifer rundkerniger Leukozyten bei der reingezüchteten Pelger-Huëtschen Anomalie der Kaninchens und die Bedeutung der Pelger-Leukozyten in der vergleichenden Hämatologie. Folia Haematol (Frankf) 1943;67:249-91.

6 Klein H. Die Pelger-Anomalie der Leukocyten und die pathologische Anatomie des neugeborenen homozygoten Pelger-Kaninchens. Z Mensch Vererb Konstitutions/ 1949:29:551-620.

7 Nachtsheim $\mathbf{H}$. The Pelger-anomaly in man and rabbit. J Hered 1950;41:131-7.

8 Haverkamp Begemann N, van Lookeren Campagne A. Homozygous form of Pelger-Huët's nuclear anomaly in man. Acta Haematol 1952;7:295-303.

9 Bernard J, Undritz E, Bru Mathé G, et al. Anomalie de Pelger homozygote chez l'homme. Sang 1956;27:819-24.

10 Ciplea AG, Ciorapciu S. Anomalie leucocytaire Pelger-Huet homozygote humaine. Presse Med 1958;15:554-5.

11 Stobbe H, Jorke D. Befunde an homozygoten Pelger-Merkmalsträgern. Schweiz Med Wochenschr 1965:95:1524-9.

12 Aznar J, Vaya A. Homozygous form of the Pelger-Huet leukocyte anomaly in man. Acta Haematol 1981;66:59-62.

13 Gastearena J, Orue MT, Perez EE, et al. Anomalía de Pelger-Huët homocigota. Sangre (Barc) 1982;27:1079-81.

14 von Siegert E, Beier L, Gräbner H. Ein Beitrag zur homozygoten Form der Pelger-Huetschen Kernanomalie. Kinderarztl Prax 1983;51:164-9.

15 Waterham HR, Koster J, Mooyer P, et al. Autosomal recessive HEM/ Greenberg skeletal dysplasia is caused by $3 \beta$-hydroxysterol $D^{14}$-reductase deficiency due to mutations in the lamin B receptor gene. Am J Hum Genet 2003;72:1013-7.

16 Greenberg CR, Rimoin DL, Gruber HE, et al. A new autosomal recessive lethal chondrodystrophy with congenital hydrops. Am J Med Genet 1988:29:623-32

17 Chitayat D, Gruber H, Mullen BJ, et al. Hydrops-ectopic calcification-motheaten skeletal dysplasia (Greenberg dysplasia): prenatal diagnosis and further delineation of a rare genetic disorder. Am J Med Genet 1993;47:272-7.
18 Horn LC, Faber R, Meiner A, et al. Greenberg dysplasia: first reported case with additional non-skeletal malformations and without consanguinity. Prenat Diagn 2000;20:1008-11

19 Offiah AC, Mansour S, Jeffrey I, et al. Greenberg dysplasia (HEM) and Xlinked dominant Conradi-Hünermann chondrodysplasia punctata (CDPX2): presentation of two cases with overlapping phenotype. J Med Genet 2003;40:e129.

20 Ciatto A, Ferretti GF. Su di un caso di anomalia di Pelger-Huet nella sue eccezionale variante omozigotica. Minerva Med 1978:69:697-700.

21 Riario-Sforza G, Salvati F, Troya C. L'anomalia granulocitaria di Pelger-Huet: prima segnalazione di due soggetti omozigoti nella stessa famiglia. Arch Sci Med (Torino) 1981;138:511-5.

22 Erice JG, Perez JM, Pericas FS. Homozygous form of the Pelger-Huet anomaly. Haematologica 1999;84:748.

23 Latimer KS, Rakich PM, Thompson DF. Pelger-Huet anomaly in cats. Vet Pathol 1985;22:370-4.

24 Latimer KS, Rowland GN, Mahaffey MB. Homozygous Pelger-Huet anomaly and chondrodysplasia in a stillborn kitten. Vet Pathol 1988;25:325-8.

25 Shultz LD, Lyons BL, Burzenski LM, et al. Mutations at the mouse ichthyosis locus are within the lamin B receptor gene: a single gene model for human Pelger-Huet anomaly. Hum Mol Genet 2003;12:61-9.

26 Madazli R, Aksoy F, Ocak V, et al. Detailed ultrasonographic findings in Greenberg dysplasia. Prenat Diagn 2001:21:65-7.

27 Trajkovski Z, Vrcakovski M, Saveski J, et al. Greenberg dysplasia (hydropsectopic calcification-moth-eaten skeletal dysplasia): prenatal ultrasound diagnosis and review of literature. Am J Med Genet 2002;111:415-9.

28 Vaya A, Garcia A, Mira Y, et al. A phenocopy of the homozygous PelgerHuet anomaly secondary to acute enteritis in a heterozygous Pelger-Huet patient. Acta Haematol 1983;70:274-5.

29 Berman M, Fried W, Knospe W. The Pelger-Huet anomaly: a new familial association with polydactyly and trisomy 13 syndrome. Acta Haematol 1983;70:275-6

30 Fishbein JD, Falletta JM. Pelger-Huet anomaly in an infant with multiple congenital anomalies. Am J Hematol 1991;38:240-2.

31 Holmer L, Pezhman A, Worman HJ. The human lamin B receptor/sterol reductase multigene family. Genomics 1998;54:469-76.

32 Kelley RI, Herman GE. Inborn errors of sterol biosynthesis. Annu Rev Genomics Hum Genet 2001:2:299-341.

33 Burke B, Stewart CL. Life at the edge: the nuclear envelope and human disease. Nat Rev Mol Cell Biol 2003;3:575-85.

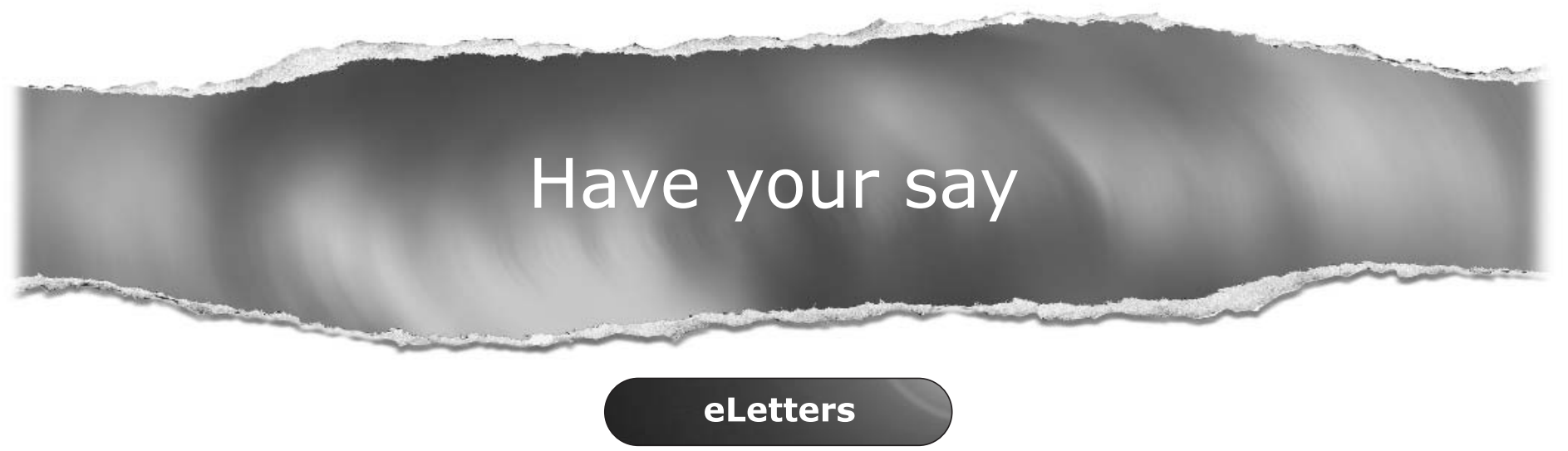

If you wish to comment on any article published in the Journal of Medical Genetics you can send an eLetter using the eLetters link at the beginning of each article. Your response will be posted on Journal of Medical Genetics online within a few days of receipt (subject to editorial screening).

\section{www.jmedgenet.com}

